\title{
The Impact of Global Transformations on the Processes of Regional and Ethnic Identity of Indigenous Peoples Siberian Arctic
}

\author{
Natalia P. Koptseva \\ Siberian Federal University, Russian Federation
}

Vladimir I. Kirko

Siberian Federal University, Krasnoyarsk State Pedagogical University named after Victor Astafiev, Russian Federation

Email: decanka@mail.ru

\section{Doi:10.5901/mjss.2015.v6n3s5p217}

Abstract

In the given article, we analyze regional identity among the native indigenous people in the Siberian Arctic region on the materials of field researches performed in the Krasnoyarsk Region (Russia) in 2010-2014. In the course of field researching they have hold an expert opinion poll, and as for the experts, there have been invited representatives of local organs of power and businessmen, who exercise traditional economic management. Experts have estimated a probability of concrete tendencies in the processes of formation of positive or negative regional ethno-cultural identity of indigenous peoples of the Siberian Arctic Region. On one hand, global transformations contribute to vanishing of the unique ethno-cultural identity of the native indigenous peoples. However, precisely global technologies give an opportunity for activation of cultural and social practices, which preserve and reproduce positive ethno-cultural identity of the native indigenous peoples of the Siberian Arctic region. One of the main places is taken by the technologies of distant education, and its content is related to ecological, economical, and cultural practices of native people of the Siberian Arctic region. Experts from among the native population consider that it is necessary to preserve the state support of traditional economic management, including rain-deer breeding, fishing, hunting, and juridical fortification of the native indigenous peoples' rights of the Siberian Arctic Region to traditional economic activity.

Keywords: regional identity, Siberian Arctic Region, indigenous peoples, expert enquiry, traditional economy

\section{Introduction}

The Siberian Arctic Region is a region, which has an important geo-political meaning. There are concentrated immense resources, the Siberian Arctic Region plays an important role in regulation of the climate of the whole planet, and ecological parameters of the given region have both international and interstate meaning (Forbes, 1999; Whiteman et al., 2013; Henry \& Tulaeva, 2013). The basic research of the Siberian Arctic Region are hold within the frames of economics, ecology and economic geography (Lee, 2013; Czaplicka, 2011; Krapivin et al., 2015). At present time, the Siberian Arctic Region represents a subject field of ethnic, cultural, northern and indigenous studies (Krupnik, 2002; Koptseva \& Kirko, 2014b; Kistova et al., 2014a). Most scientists suppose that ethnic groups of the Siberian Arctic Region are specific socialanthropological societies, which predetermine economical, political, and cultural dynamics of the northern and arctic territories (Shyshatskiy et al., 2012). Thereat, social-anthropological and ethno-cultural space of the Siberian Arctic Region is very complicated and demands complex inter-disciplinary scientific researching (Nuttall, 2000; Kistova et al., 2014b). Processes of the Siberian Arctic regional identity are defined by the joint co-residence of four ethno-cultural flows on the given territory: 1) $87 \%$ of population are the Russians; 2) autochthonous population forms $0.5 \%$; 3) indigenous ethnic groups, including the Tartars, the Ukrainians, the Byelorussians, the Polacks, the Germans, the Azerbaijanians, the Chuvashes, the Udmurts and many others (totally about 150 kinds of ethnos according to the 2010 All-Russia Census) - that is more than $12 \%$ of population; 4) temporary labor migrants (mainly, from Central Asia and South Caucasus), whose number grows annually.

Modern scientists, researchers of the economic development processes of the Siberian Arctic regional identity, consider not one, single, but a multiple number of various multidirectional scenarios of this region development, including quite negative variants (Shephard, 2015; Struzik, 2015; Koptseva \& Kirko, 2014b; Smith, 1991). In scientific discussions, they single out processes of deprivation of unique social and cultural practices of indigenous peoples of the Siberian 
Arctic Region, and general social ill-being of these ethno-cultural groups (Slezkine, 1994). In the cultural sphere there exist simultaneously myths about the North and Siberia as about some sacred space, and they develop a theme of peculiar "northern" or "circumpolar" civilization, shamanism as a religious basis of the regional cultural identity of the indigenous people, they create images of special ecological community, wherein northern people and northern nature coexist in their original ancient harmony (Reznikova, 2015; Sitnikova, 2014; Smolina, 2015; Seredkina, 2014). Researchers pay special attention to the unique economic and cultural practices of the indigenous people of the Siberian Arctic Region, and they are very anxious about the fact, that these unique economic, ecological and cultural practices will vanish, as soon as the languages of the native people and ethnic processes of the indigenous people's self-identification disappear, (Sillanpää, 2015; llbeykina, 2014).

In the second decade of the XXI century, the Siberian Arctic Region is a space for reindustrialization (Harsem et al., 2015; Yakovleva, 2011). Large companies-users of mineral resources have come to this territory (Luzan, 2014), and these companies predetermine urbanization of these territories, that in its turn, accelerates the processes of westernization, country-wide assimilation of the modern mass culture values, transformation of the unique ethno-cultural communities into a global society of common consumption, and disappearance of unique languages of the native people (Hough, 2015).

What kind of global transformations can influence or already having significant influence on the processes of regional identification in the sphere of ethno-cultural groups of the native people of the Siberian Arctic Region? To a greater or lesser degree, we speak about all these modern globalization processes: political, economic, and cultural (Zamaraeva, 2014). Thus, in order to solve concrete political targets of indigenous peoples of the Siberian Arctic Region it is not enough to use the mechanisms of the modern national state. Most native people of the Siberian Arctic Region actually live not in one, but in two states at a time. The notion of state administrative-territorial border for their traditional ideology has much lesser meaning than for a modern society's man. Development of economic global commercial relations predetermines the features and the qualities of basic goods, which are consumed by the representatives of the Siberian Arctic Region people. At the same time, the goods, which those people can produce, are not competitive in comparison with the goods of the global industrial corporations. Almost all the industries in the areas of compact settlement of the native peoples of the Siberian Arctic Region, being related to the traditional economic activities, are donated and will not be able to survive without special state support.

Global transformations of cultural organizations are of special meaning for the regional identity processes in the sphere of the native peoples of the Siberian Arctic Region. Development of mass media and mass communication, tourism development, spreading of social global ideology and social science predetermine a demise of unique local ethnic cultures, an erosion of proper cultural identity. Globalization can result in a loss of ethnic peculiarities and variety of cultures (deformation of ethnic values), that is why it is so important for the native people of the Siberian Arctic Region to stimulate the struggle for the ethnic cultural revival. Global transformation, in its extreme form, influences indigenous people of Siberian Arctic Region in such a way that, they lose their cultural originality. One can observe certain unification of their cultural worlds (vanishing of the national basic cultural values), exacerbation of ethno-cultural identity crisis, which leads to destabilization and to degradation of the native languages' status or even deformation of their structures. At the same time, in the processes of regional identification of the Siberian Arctic indigenous people we can also see certain opposite processes, which result in actualization of their original ethnic identity (Ulturgasheva et al., 2014; Vitebsky, 2005).

In the nearest future the processes of economic, political, and cultural development of the Siberian Arctic Region will be mostly determined by complex interrelations between global transformations and modern tendencies in the processes of ethnic identification and self-identification of indigenous people of the Siberian Arctic Region and by the appearance of new forms of ethnic regional identities, which have not existed before. The given research is dedicated to analysis of these forms of ethnic identities and their influence on the Siberian Arctic regional space.

\section{Literature Review}

Regional identity processes are comprehended by the modern scientists in the context of topical political practices of regional elites and the given political practices allow resisting of global transformations. Regional identification is a result of social-political constructing: new political resources are formed, new actors appear, those who connect their political activity with the given territory (Wilson, 2015). Modern processes of regional identification cannot be any more limited by economic and/or political sphere. Basic social and cultural processes have significant influence on formation of new regional identities. Nevertheless, econometric researchers of the modern regions are extremely important for demonstration of inner peculiarities of these regions (Glickman, 2014). A. Paasi (2003) defines "regional identity" as a 
process of creation of territorial borders, symbolism and institutes. Problematics of regional identity is especially popular in cultural, political and economic geography. Processes of regional identity are closely related with the processes of ethnic and cultural identity. A. Paasi supposes that regional identity is a part of political practices, connected with differentiation of social sphere. The scientist considers that usage of the term "regional identity" should have a certain substantiation, as far as it is used precisely for political purposes (Paasi, 2002).

Regional identities are characteristic of complicated processes on the borders of the Northern national states, for example, on the borders of Swaziland and Finland. Identification and differentiation on the borders of ethnic communities have a complicated basement of various social practices (Prokkola et al., 2015).

Positive meaning of regional identity is concluded in its ability to mobilized people in their striving for common targets and for formation of a commonwealth, and it is as well an efficient technology for planning of concrete territory's development (Raagmaa, 2002). However, regional identity itself plays an ambiguous role in the regions' development: 1) it can be a successful activation for population; 2) it can be inefficient; 3) and it can serve as a barrier or an obstacle for certain region's development (Semian \& Chromý, 2014).

Processes of regional identification can be based on steady and fast foundations - cultural and historical, which have stood the test of time, and simultaneously, new processes of regional identification are connected with the processes of economic competitiveness of a concrete region. These new processes form not a very steady base for a positive social identification. And, at the same time, the processes of globalization interfere with the creation of new regional collective identities (Terlouw, 2012).

Regional identity of the Siberian Arctic indigenous peoples is predetermined by extreme climatic and landscape circumstances of circumpolar zone of their habitation (Slezkine, 1994; Andersen, 2000). However, today these extreme conditions are also a result of influence of the global ecological problems. Certain scientists survey the matters of food security of the Siberian Arctic indigenous peoples, and they mark that traditional food and water, being used by these nations, are polluted by the industrial waste products (Dudarev et al., 2013). The researchers of Yamal suppose that global economic transformations destroy traditional ways of indigenous peoples' wandering and rein-deer breeding, and in conjunction with the global warming, it becomes a threat to the steadiness of socio-ecological system of the Siberian Arctic Region (Forbes et al., 2009). At the same time, the scientists consider that the Arctic warming has influence on the growth of sea fish harvest of the indigenous people of circumpolar zone of US, Canada and Russia (Zeller et al., 2011). And, in its turn, the increase of the volume of the sea fish harvest of the indigenous people has an impact on the whole ecosystem of the Arctic Region.

Positive influence of the Siberian Arctic global transformations can be related with the development of modern educational remote technologies, which let the Siberian Arctic native peoples get necessary education in traditional places of their habitation (Kovalevsky et al., 2014). It is also very important because, according to the medical research, urbanization and modernization cause an excessive stress to the Siberian native peoples (Kozlov et al., 2003).

According to the mind of political experts, who study indigenous peoples of the Siberian Arctic Region, there is one more kind of important positive influence of the global transformations. It is the political processes, related to development of local self-government of the indigenous peoples, and their understanding of economic, political and cultural rights they really possess and the mechanisms, which can help them to realize these rights (Osherenko, 1995).

Among the Siberian Arctic regions, a special place is taken by the Krasnoyarsk Region, which is inhabited by nine indigenous native nations (the Nenets, the Evenkis, the Nganasans, the Kets, the Selkups, the Chulyms, the Yessey Yakuts, the Dolgans, and the Enets). Our survey of the global transformation effect on the regional identity of the Krasnoyarsk indigenous people let us widen and make more detailed the comprehension of these processes from the point of view of political management as well.

\section{Research Methodology}

The leading method of research of the global transformation impact on the regional identities in the sphere of indigenous peoples of the Siberian Arctic Region on the whole and of the Krasnoyarsk Region in particular, - these are field researches, including overt observations, focus-groups, photo- and video-shooting, expert interviewing, questioning, having been made by the scientists, aspirants and students of the universities (the Siberian Federal University, the Krasnoyarsk State Teachers' Training University n.a. Victor Astfiev, the Krasnoyarsk State Medical University, the Krasnoyarsk State Agrarian University in the period of 2010-2014.) (Libakova \& Sertakova, 2015; Koptseva \& Kirko, 2014a; Koptseva \& Kirko, 2014b). Overall, there have been organized eight complex expeditions to the places of compact settlement of the Evenkis, the Dolgans, the Nenets, the Selkups, the Chulyms, and the Yessey Yakuts. The scientists have made researches in the Farcovo village (the Turukhansk Region), and besides in the settlements Surinda, Yessey 
(Evenkiya), Nosok, Karaul, Khatanga (Taimyr). In those field surveys took part specialists in the sphere of northern and indigenous researches, economists, culture scientists, medical specialists, builders, architects, and tutors.

In accordance with the modern methodological requirements, native indigenous studies must be hold in collaboration with the representatives of the native peoples (Krupnik \& Vakhtin, 1997; Pimenova, 2015). In correspondence with the mentioned above, 27 representatives of the native Siberian Arctic peoples have participated in the given researches, including political and social leaders, businessmen, tutors, head officials of the industrial enterprises, hunters, fishermen, and rein-deer breeders (Libakova et al., 2014).

\section{Findings and Discussion}

Regional identity in the sphere of indigenous peoples of the Krasnoyarsk region is closely related to the processes of ethic identification and self-identification. In the course of field surveys the experts have had to estimate 1) the probability and 2) the significance of basic social and cultural processes, which influence on the regional and ethno-cultural identity of indigenous peoples of the Krasnoyarsk region, according to the five-mark grading system ( 5 points is a very high probability / significance; 4 points is high; 3 points is medium; 2 points is low; 1 point is a very low probability I significance).

On the bases of the given research, it is necessary to fix a negative emotional grading of the regional identity in the sphere of indigenous people of the Krasnoyarsk region. Thus, the highest number of points has been given by the experts (also from the number of native people) to such a negative practice as "significant increase of drug and alcohol addicted people among the representatives of the native peoples" -4.3 points. Above the average have estimated the experts the probability of such a tendency as "termination of reproduction of some kind of northern ethnos in the nearest two generations" - 3.4 points. Quite a low estimation has been given to the tendency of "demography development of the Siberian indigenous peoples, which coincide with the pan-Russian and over-world tendencies, related to the demographic transition from the traditional to the modern type of population reproduction; stabilization of indigenous peoples' numerosity" -2.6 points. The same low grade has been given by the local experts to the probability of implementation of such a social practice as "increase of economic and social stimulation of the local population to the healthy way of living" -2.5 points. However, the tendencies themselves seem to be very significant. The meaning of the tendency "termination of reproduction of some kind of northern ethnos in the nearest two generations" has been evaluated very high by the experts - 4.6 points. Almost the same number of points has been given to such a tendency as "deterioration of the demographic situation, increase of depopulation and increase of the meaning of socio-economic factors in demographic development of the Northern peoples" - 4.4 points. The experts suppose that regional identities in the sphere of indigenous population will be subjected to the influence of global transformation, but the youth of the native peoples will retain their ethnic self-identification in its full form in the nearest 15-20 years. Such an educational practice, which contributes to ethnic self-identification, as "preservation of traditional forms of education (secondary education and highprofessional education) on the areas of indigenous peoples' living" has been evaluated by the experts in 3.8 points. All the experts without exclusion have put ethno-cultural education on the first place by its significance as a basic practice of positive regional identity. The experts have estimated the tendency - "teaching the school pupils of original kinds of catching; implementation of basic educational programs of rein-deer breeding, fur-farming, hunting, household keeping, and sewing of national clothes as obligatory subjects; obligatory course of curricular practical training in kinship communities, rein-deer breeding teams, fishermen settlements and so on." by the highest grade of 5 points.

Much higher than an average mark has been given by the experts to the probability of regional identity loss in the sphere of native kinds of ethnos. The probability of the tendency "indigenous peoples' loss of original traditional folk arts" has been valued in 3.8 points; "appearance of the «ethnic revival» phenomenon, which will give a strong basis for the processes of preservation and development of indigenous peoples" - 3.2 points; "indigenous peoples' cultural identity extinction" - 3 points; "steady existence of the northern kinds of ethnos under the circumstances of industrial and mass culture expansion on the territory of their habitation" - 2.8 points; "improvement of efficiency of the state program of indigenous peoples' economic and culture development" -2.7 points. To the mind of the experts, the tendency of environment pollution level decrease (air, water, and soil), preservation of the native peoples' natural environment have the biggest significance for the northern territories, (4.7); and the lowest rate has got the creation of "reserved zones of habitation" or compulsory integration into "industrial future" $(2,9)$.

In the context of processes, which define the specifics of regional identification of indigenous peoples of the Krasnoyarsk region, the following question has become very important: "evaluate the probability of possible risks and significance of critical situations in the sphere of indigenous peoples' supply for the period up to 2060". The highest possible rate of the experts according to the criterion of probability - 5 points - has been given to the tendency "wasteful 
spending of "the basic human resource" - dying of the leading culture holders among the representatives of indigenous peoples, striving of the new generations for western culture, for western values (2015-2060)". According to the criterion of significance, all the experts have estimated this tendency by the highest grade -4.2 . The following estimations of the experts speak of the state paternalism as a foundation of economic practices of the indigenous peoples. They have estimated the tendency "cancelation of state financing, insufficiency of their own financial means for investments of preservation and development of the Northern native peoples (2015-2060)" lower than average - 2.9 points. At the same time, they suppose that the most insignificant tendencies are the following: "cumulative effect of educational, social and territorial stratification on the areas of the native peoples' settlement, increase of social tension (2015-2060)" - 3.7 points; "infrastructure crisis on the territories of habitation of SIPN (2015-2060) - decrease of transport connectivity, building exhaustion and unworthiness of domestic and administrative buildings for renovation" have been also given 3.7 points.

Most significant in the given context are considered to be the following risks and critical situations: 1) wasteful spending of «the basic human resource» - dying of the leading culture holders among the representatives of indigenous peoples, striving of the new generations for western culture, for western values, (2015-2060) - 4.4 points; 2) transformation of indigenous peoples' habitation territories into an arena of competition of various its "assimilating" subjects (Russian and foreign oil- and gas-producing companies) with negative consequences for their socio-economic development (2015-2060) - 4.2 points; 3) crisis of management (2015-2060) - deficit of strategies, political will, managerial technologies and managerial stuff, which allow to get the planned changes, important for preservation and development of indigenous peoples - 4.2 points; 4) ideological crisis (2015-2060) - increase of disagreement in social notions about "righteous" life of SIPN; absence of a clear and attractive perspective of preservation and development of traditional forms of household, folk arts and so on - 4 points; 5) attaching of a role of "resource colonies" with a low level of investments into the human capital to indigenous peoples' habitation territories (2015-2060) - 4 points; 6) cancelling of state financing, lack of own financial means for investments for preservation and development of the indigenous peoples' budget (2015-2060) - 4 points; 7) significant decrease of the native peoples' numerosity on the territory of Russian Federation (2015-2060) because of demographic recession and increasing migration outflow -3.8 points.

The obtained results of the experts' questionnaire have been discussed at the expert round tables in the presence of members of public organizations, which defend the rights of indigenous peoples, in the presence of representatives of regional organs of power, organs of local self-government, scientists, aspirants, and representatives of native peoples, leading a traditional way of life.

\section{Concluding Remarks}

1. Global transformations influence ambiguously on the processes of regional identity of the indigenous peoples of the Siberia Arctic Region. They generate a threat of ethno-cultural identity vanishing, but at the same time, they cause an increase of indigenous peoples' activity in order to preserve and reproduce their own unique economic, ecological and cultural practices, related to extreme conditions of living on the circumpolar zone. The experts (including the local ones out of the number of the indigenous peoples) consider that in order to preserve the unique cultural practices one need to apply the modern education technologies and preserve the traditional ways of household keeping (rein-deer breeding, hunting, fishing).

2. Political management of the Siberian Arctic territories should take into account multi-directionality of the processes, related as to negative, so to positive results of the global transformations for the native people of the unique region.

\section{References}

Czaplicka, M. (2011). Aboriginal Siberia: A Study in Social Anthropology. With a Preface by RR Marett. Adegi Graphics LLC.

Dudarev, A. A., Alloyarov, P. R., Chupakhin, V. S., Dushkina, E. V., Sladkova, Y. N., Dorofeyev, V. M., \& Evengård, B. (2013). Food and water security issues in Russia I: food security in the general population of the Russian Arctic, Siberia and the Far East, 20002011. International journal of circumpolar health, 72 .

Forbes, B. C. (1999). Land use and climate change on the Yamal Peninsula of north-west Siberia: some ecological and socio-economic implications. Polar Research, 18(2), 367-373.

Forbes, B. C., Stammler, F., Kumpula, T., Meschtyb, N., Pajunen, A., \& Kaarlejärvi, E. (2009). High resilience in the Yamal-Nenets social-ecological system, West Siberian Arctic, Russia. Proceedings of the National Academy of Sciences, 106 (52), 2204122048.

Glickman, N. J. (2014). Econometric analysis of regional systems: Explorations in model building and policy analysis. Academic Press.

Harsem, Ø., Heen, K., Rodrigues, J. M. P., \& Vassdal, T. (2015). Oil exploration and sea ice projections in the Arctic. Polar 
Record, 51(01), 91-106.

Henry, L. A., \& Tulaeva, S. A. (2013). Reindeer, Oil, and Climate Change: Pressures on the Nenets Indigenous People in the Russian Arctic.

Hough, P. A. (2015). International Politics of the Arctic. Routledge.

Ilbeykina, M. (2014). Indigenous Peoples as a Research Space of Visual Anthropology. Journal of Siberian Federal University. Humanities and Social Sciences, 9 (7), 1471-1493.

Kistova, A., Koptseva, N., Pimenova, N., \& Reznikova, K. (2014a). Cultural and Anthropological Studies of Indigenous Peoples of Krasnoyarsk Krai Childhood (based on the field studies of Siberian Federal University in 2010-2013). Journal of Siberian Federal University. Humanities and Social Sciences, 8 (7), 1312-1326.

Kistova, A., Pimenova, N., Zamaraeva, J., \& Reznikova, K. (2014b). Research possibilities for studying the indicators of quality of life of indigenous peoples of the North (based on the study of indigenous peoples of the North of Russia). Life Science Journal, 11(6s).

Koptseva, N. P., \& Kirko, V. I. (2014a). Modern specificity of legal regulation of Cultural Development of the Indigenous Peoples of the Arctic Siberia (the Altay Region, the Zabaikailsky Region, Republic of Buryatia, Russia). Life Science Journal, 11(9).

Koptseva, N. P., \& Kirko, V. I. (2014b). The information basis for formation of positive ethnic identities in the process of acculturation of indigenous peoples of the Arctic Siberia (Krasnoyarsk, Russia). Life Science Journal, 11(8).

Kovalevsky, V., Kirko, V., Malakhova, E., \& Vasilyev, E. (2014). Implementation of Distance Educational Process under Conditions of Remote Settlement with Limited Access to High Speed Internet Network. Journal of Siberian Federal University. Humanities and Social Sciences, 12 (7), 2034-2041.

Kozlov, A. I., Vershubsky, G., \& Kozlova, M. (2003). Stress under modernization in indigenous populations of Siberia. International journal of circumpolar health, 62(2).

Krapivin, V. F., Varotsos, C. A., \& Soldatov, V. Y. (2015). The Arctic Environmental Problems. In New Ecoinformatics Tools in Environmental Science (pp. 487-588). Springer International Publishing.

Krupnik, I. (2002). Arctic adaptations: native whalers and reindeer herders of northern Eurasia. Dartmouth College Press.

Krupnik, I., \& Vakhtin, N. (1997). Indigenous knowledge in modern culture: Siberian Yupik ecological legacy in transition. Arctic Anthropology, 236-252.

Lee, J. (2013). Indigenous People and Political Agenda: the Issue of Social and Ecological Change of the Nomadic Siberian, the Evenki, in Russia. Journal of Contemporary Anthropology, 4(1), 1.

Libakova, N., \& Sertakova, E. (2015). The Method of Expert Interview as an Effective Research Procedure of Studying the Indigenous Peoples of the North. Journal of Siberian Federal University. Humanities and Social Sciences, 1 (8), 114-129.

Libakova, N., Sitnikova, A., Sertakova, E., Kolesnik, M., \& Ilbeykina, M. (2014). Interaction of the Yakut ethnicity and biological systems in the territory of the Sakha Republic (Hordogoy settlement, Suntarsky District) and Krasnoyarsk Krai (Essey settlement, Evenks District). Life Science Journal, 11(6s).

Luzan, V. (2014). Mechanisms of Interaction Between the State, Businesses and Small-Numbered Indigenous Peoples of the Russian Federation Under Global Transformations. Journal of Siberian Federal University. Humanities and Social Sciences, 8 (7), $1327-$ 1341.

Nuttall, M. (2000). Indigenous peoples, self-determination, and the Arctic environment. The Arctic: Environment, People, Policy, $377-409$.

Osherenko, G. (1995). Indigenous political and property rights and economic/environmental reform in Northwest Siberia. Post-Soviet Geography, 36(4), 225-237.

Paasi, A. (2002). Bounded spaces in the mobile world: deconstructing 'regional identity'. Tijdschrift voor economische en sociale geografie, 93(2), 137-148.

Paasi, A. (2003). Region and place: regional identity in question. Progress in human geography, 27(4), 475-485.

Pimenova, N. (2015). Indigenous peoples in the present situation: the scope and content of the concept [Korennye narody $v$ sovremennoy situatsii: objem i soderghanie ponyatiya]. Sociodynamica, 1, 112-134. [in Russian]

Prokkola, E. K., Zimmerbauer, K., \& Jakola, F. (2015). Performance of regional identity in the implementation of European cross-border initiatives. European Urban and Regional Studies, 22(1), 104-117.

Raagmaa, G. (2002). Regional identity in regional development and Planning. European Planning Studies, 10(1), 55-76.

Reznikova, K. (2015). "The Oera Linda Book" and "The Snow Queen": Two Destinies of One Myth. Journal of Siberian Federal University. Humanities and Social Sciences, 1 (8), 149-174.

Semian, M., \& Chromý, P. (2014). Regional identity as a driver or a barrier in the process of regional development: A comparison of selected European experience. Norsk Geografisk Tidsskrift-Norwegian Journal of Geography, 68(5).

Seredkina, N. (2014). Revisiting Methodological Principles of Cultural-Semiotic Approach in Studying Art of Indigenous Peoples of the North, Siberia and the Far East. Journal of Siberian Federal University. Humanities and Social Sciences, 8 (7), 1342-1357.

Shephard, R. J. (2015). Health and Fitness in Prehistory, Including Inferences from the Current Lifestyle of Indigenous Populations. In An Illustrated History of Health and Fitness, from Pre-History to our Post-Modern World (pp. 1-72). Springer International Publishing.

Shyshatskiy, N., Kirko, V., \& Keush, A. (2012). Problems of Modernization of the Economy of the Northern Territories. Journal of Siberian Federal University. Humanities and Social Sciences, 9 (5), 1246-1251.

Sillanpää, L. (2015). The Challenge of Language. In Cultural and Linguistic Minorities in the Russian Federation and the European Union (pp. 169-187). Springer International Publishing.

Sitnikova, A. (2014). The Concept of "North" in the Works by Rockwell Kent. Journal of Siberian Federal University. Humanities and 
Social Sciences, 8 (7), 1358-1380.

Slezkine, Y. (1994). Arctic mirrors: Russia and the small peoples of the North. Cornell University Press.

Smith, E. A. (1991). Inujjuamiunt Foraging Strategies: Evolutionary Ecology of an Arctic Hunting Economy. Transaction Publishers.

Smolina, M. (2015). The Image of Indigenous Peoples of Siberia in D.I. Karatanov Creative Work. Journal of Siberian Federal University. Humanities and Social Sciences, 1 (8), 175-195.

Struzik, E. (2015). Future Arctic. Island Press.

Terlouw, K. (2012). From thick to thin regional identities? GeoJournal, 77(5), 707-721.

Ulturgasheva, O., Rasmus, S., Wexler, L., Nystad, K., \& Kral, M. (2014). Arctic indigenous youth resilience and vulnerability: Comparative analysis of adolescent experiences across five circumpolar communities. Transcultural psychiatry, 51(5), 735-756.

Vitebsky, P. (2005). The reindeer people: living with animals and spirits in Siberia. Houghton Mifflin Harcourt.

Whiteman, G., Hope, C., \& Wadhams, P. (2013). Climate science: Vast costs of Arctic change. Nature, 499(7459), $401-403$.

Wilson, G. A. (2015). Community resilience and social memory. Environmental Values.

Yakovleva, N. (2011). Oil pipeline construction in Eastern Siberia: Implications for indigenous people. Geoforum, 42(6), 708-719.

Zamaraeva, Ju. (2014). What are Global Transformations Experienced by the Indigenous Peoples of the North? Journal of Siberian Federal University. Humanities and Social Sciences, 10 (7), 1705-1718.

Zeller, D., Booth, S., Pakhomov, E., Swartz, W., \& Pauly, D. (2011). Arctic fisheries catches in Russia, USA, and Canada: baselines for neglected ecosystems. Polar Biology, 34(7), 955-973. 
